\title{
High School Physics Teacher's Profile In Teaching For Improving Student's Energy Literacy
}

\author{
Soni Sukendar ${ }^{1 *}$, Agus Setiawan ${ }^{2}$ \\ ${ }^{1}$ Pusat Pengembangan dan Pemberdayaan Pendidik dan Tenaga Kependidikan IPA \\ ${ }^{2}$ Program Studi Pendidikan IPA Sekolah Pascasarjana UPI \\ Corresponding Author. Email: soni.sukendar@kemdikbud.go.id
}

\section{Keywords: \\ Energy Literacy, Physics Learning, Teacher Profile}

\begin{abstract}
The research has been conducted to find out the profile of high school physics teacher in learning that develop student energy literacy. The method used in the research is descriptive-analytics using questionnaires that are distributed to high school physics teachers in MGMP district/city. The data are energy literacy understanding, energy literacy implementation in daily life, ability in developing learning, obstacles, and training needs. Based on the results of data analysis, it can be concluded that high school physics teacher has not yet understood the concept of energy literacy, although it has been implemented in daily life. Physics learning has not yet developed student energy literacy. Therefore it is necessary to develop blended training mode in MGMP.
\end{abstract}

C2018 JSER. Yogyakarta State University.

\section{INTRODUCTION}

Energy use has a major impact on people's living standards and every major economic sector. The latest issue on climate change mitigation demands attention to energy efficiency and energy use reduction to achieve sustainable economic growth (Chen, et.al., 2013). Indonesia is a major source of energy and energy users. The problems facing Indonesia in the energy sector are fossil energy reserves that are dwindling, the limited access to energy for the community, and the development of alternative energy that is constrained by technological mastery and low financing (BPPT, 2016).

Strategies in dealing with energy issues are increasing the capacity of fossil fuel exploration, utilization of new and renewable energy resources, migration of energy consumption patterns in various sectors (BPPT, 2016). It is no less important is the awareness and participation of the community in addressing energy problems (Akitsu, et al., 2017). People are expected to have energy literacy (Cetin \& Nisanci, 2010).

Research on energy literacy has been widely practiced over the past two decades. Energy Literacy is an educational endeavor that helps pave the way for a safer energy future by empowering individuals to choose appropriate energy-related behaviors throughout their daily lives (DeWaters \& Powers, 2011). The framework of developing the energy literacy instrument has been developed covering three aspects of outcome components namely cognitive, affective, and behavioral (DeWaters \& Powers, 2011). Contextualized instruments can assess the energy literacy of SMP and SMA students in a multidimensional way (Chen, et al., 2015). Utilization of computer-based tests can reach a wider population (Chen, et al., 2014). Energy and climate literacy should be combined and ideally incorporated into the school curriculum (McCaffrey, 2015). Energy Literacy can be achieved through the education sector (Bamisile, et al., 2016; Hendrickson, et al., 2014; Singhirunnusorn, et al., 2011).

Schools in Indonesia are expected to contribute to the energy literacy of students as well as the community. This hope is in line with the literacy movement programmed by the Indonesian government through the Ministry of Education and Culture. In addition, learning what happened today just transferring knowledge to students, and still centered on the teacher. This leads to not 
getting the experience to understand the concept in full by the student (Sukardiyono \& Rosana, 2017).

Energy literacy is more closely related to science, physics, chemistry, and biology (DOE, 2017). In terms of competency attitudes, knowledge and skills in the 2013 curriculum, high school physics subjects have the potential to grow and develop energy literacy (Yusup, 2017). The role of high school physics teacher is quite important in membelajarkan physics that can cultivate energy literasi.

The issues to be answered in this paper are:

1. How is the understanding of high school physics teachers on the concept of Literacy Energy in Learning?

2. How far is the implementation of physics learning in order to develop student energy literacy?

3. How does the training program fit the teacher's needs?

\section{METHODS}

The instrument was developed in a questionnaire form referring to Table 1 . The discussion focused on the teacher's claim in responding to the questionnaire.

Respondents were randomly selected by distributing an online questionnaire to high school physics teachers in the district / city MGMP. The participating physics teachers responded to a questionnaire of 196 from NAD, Jambi, Lampung, North Sumatera, West Sumatera, South Sumatra, Riau Islands, Riau, Kep. Bangka Belitung, Banten, DKI Jakarta, West Java, Central Java, East Java, DIY, Bali, West Kalimantan, South Kalimantan, South Sulawesi, and West Papua.

Quantitative analysis is conducted to describe teachers' perceptions of energy literacy and their contribution in physics learning from planning, implementation and assessment of learning.

\section{RESULTS}

\section{Understanding the concept of energy literacy in learning}

Understanding the concept of energy literacy in the studied study involves: explaining the concept of energy literacy, applying energy literacy in everyday life, determining high school physics content related to energy literacy, and identifying potential local environments (context) that can be used as a source of learning about literacy energy. Based on the response to the questionnaire that has been dispersed, the data obtained as presented in Table 2.

Table 1. Teacher Competencies Expected to Foster Student Energy Literacy

\begin{tabular}{|c|c|}
\hline dicators: & \\
\hline & 1. Explain the concept of energy literacy \\
\hline & 2. Applying energy literacy in everyday life \\
\hline & 3. Recognizing the importance of energy literacy in learning \\
\hline & $\begin{array}{l}\text { 4. Determine the content of high school physics associated with energy } \\
\text { literacy }\end{array}$ \\
\hline & $\begin{array}{l}\text { 5. Identify potential local environments (contexts) that can be used as sources } \\
\text { of learning about energy literacy }\end{array}$ \\
\hline B. Implementi & g Energy Literacy in Physics Learning \\
\hline Indicators: & \\
\hline 1. Basic & 1. Identify KD physics SMA associated with energy literacy \\
\hline $\begin{array}{l}\text { Competen } \\
\text { ce }\end{array}$ & $\begin{array}{l}\text { 2. Develop indicators of achievement of competencies associated with energy } \\
\text { literacy }\end{array}$ \\
\hline 2. Lesson & 3. Choosing a learning strategy that can supply energy literacy \\
\hline plan & 4. Preparing energy-laden literacy learning scenarios \\
\hline 3. Materials & $\begin{array}{l}\text { 5. Prepare teaching materials for physics learning that is filled with energy } \\
\text { literacy }\end{array}$ \\
\hline 4. Worksheet & 6. Preparing LKS for physics learning which is loaded with energy literacy \\
\hline 5. Media & 7. Choosing a medium for physics learning that has energy literacy \\
\hline & 8. Develop a medium for physics learning that is charged with energy literacy \\
\hline 6. Evaluation & $\begin{array}{l}\text { 9. Develop a test instrument for indicators of achievement of competencies } \\
\text { related to energy literacy }\end{array}$ \\
\hline & $\begin{array}{l}\text { 10. Develop non-test instruments for indicators of achievement of } \\
\text { competencies related to energy literacy }\end{array}$ \\
\hline
\end{tabular}


Table 2. Profiles of High School Physics Teachers in Understanding The Concept of Energy Literacy in Learning

\begin{tabular}{|c|c|c|}
\hline No & Indicators & Teacher's response \\
\hline 1. & $\begin{array}{l}\text { Explain the concept of } \\
\text { energy literacy }\end{array}$ & $\begin{array}{l}\text { - } 8 \% \text { mastering the concept of energy literacy } \\
\text { - } 1 \% \text { know the energy yield component (outcome) }\end{array}$ \\
\hline 2. & $\begin{array}{l}\text { Applying energy literacy in } \\
\text { everyday life }\end{array}$ & $\begin{array}{l}\text { - } 39 \% \text { care about the electricity savings in schools } \\
\text { - } 76 \% \text { save water } \\
\text { - } 68 \% \text { turn off the room lights when left } \\
\text { - } 72 \% \text { saving energy at home } \\
\text { - } 72 \% \text { shut down the computer when left abandoned }\end{array}$ \\
\hline 3. & $\begin{array}{l}\text { Recognizing the importance } \\
\text { of energy literacy in learning }\end{array}$ & $\begin{array}{l}\text { - } 99 \% \text { considers it important to integrate energy literacy } \\
\text { content in physics learning }\end{array}$ \\
\hline 4. & $\begin{array}{l}\text { Determines the content of } \\
\text { high school } \begin{array}{r}\text { physics } \\
\text { associated with energy } \\
\text { literacy }\end{array}\end{array}$ & $\begin{array}{l}\text { - Respondents have difficulty integrating energy literacy } \\
\text { content on "quantum concepts and phenomena" }\end{array}$ \\
\hline 5. & $\begin{array}{l}\text { Identify potential local } \bullet \\
\text { environments (contexts) } \\
\text { that can be used as } \\
\text { sources of learning about } \\
\text { energy literacy }\end{array}$ & $\begin{array}{l}100 \% \text { can identify potential local environment.. } \\
53 \% \text { of respondents have never utilized the potential of } \\
\text { the surrounding environment as a learning resource } \\
\text { relevant to "Energy Literacy" }\end{array}$ \\
\hline
\end{tabular}

From the data it can be seen that high school physics teachers do not know comprehensively the concept of energy literacy, although in fact they have implemented or behaved to apply energy literacy in everyday life. As a member of the community, this condition is good, but as a teacher who is obliged to instill energy literacy, then the teacher must master his theory as well. The respondents had no difficulty in determining the physical content and identifying the environmental potential to be used. However, such claims need to be compared with their claims to the development of their learning.

\section{Implementation of Physics Learning}

The ability of physics teacher in implementing physics learning which grow energy literacy can be seen from the indicators of part B in Table 1. Based on the response to the questionnaire that has been spread, the data obtained as presented in table 3.

Table 3 shows that high school physics teachers still have difficulty in planning and implementing learning that fosters student energy literacy.

\section{Teacher Training Needs}

Training needs analysis (TNA) is obtained by identifying the difficulties that teachers face in implementing the learning as well as the desired form of training. Based on the response to the questionnaire that has been spread, obtained the data as follows. Most respondents claim to have difficulties in integrating energy literacy content in physics learning, in the form of:

a. Lack of reference: $70 \%$

b. No training: $87 \%$

c. Limited subject matter: $42 \%$

d. Limited KD-KD relevance: $58 \%$

e. Developing RPP: $56 \%$

f. Developing Lesson Materials: $84 \%$

g. Developing LKS: $84 \%$

h. Absence of media: $85 \%$

i. Developed test and non test instruments: $74 \%$

j. Limited time: $84 \%$

k. Other obstacles include student interest, government support, and sarpras.

While the form of training desired by the respondents is presented in Table 4 . Based on the data in Table 4, it can be concluded that training should (1) not be implemented on weekdays, only on MGMP days only. (2) using a combined / blended mode between face-to-face and online modes. (3) Training duration per day maximum 4 JP. (4) Methods vary and there needs to be an assignment. Subject of training required by high school physics teachers is presented in Table 5 . 
Table 3. Profiles of High School Physics Teachers in Implementing Learning That Fosters Student Energy Literacy

\begin{tabular}{ll}
\hline No & \multicolumn{1}{c}{ Indicators } \\
\hline 1. & $\begin{array}{l}\text { Identify KD physics SMA } \\
\text { associated with energy literacy }\end{array}$
\end{tabular}

2. Develop indicators of achievement of competencies associated with energy literacy

Respondents have difficulty integrating energy literacy content for the following KD.
a. Kls X : topik pengukuran (KD 3.2, 4.2), topik vektor (KD $3.3,4.3)$, topik gerak parabola (KD 4.5)
b. Kls XI : topik kesetimbangan benda tegas (KD 4.1), topik pemantulan dan pembiasan (KD 4.11)
c. Kls XII : -
3. Choosing a learning strategy that can supply energy literacy

- $63 \%$ respondents have not developed indicators associated with energy literacy

- $35 \%$ formulation Indicator made by respondent correct

- $55 \%$ respondents do not know the learning strategy to supply energy literacy

- $13 \%$ respondents can formulate correctly

4. Prepare energy literacy laden - $67 \%$ respondents have not yet prepared energy-laden learning scenarios

\section{scenario}

5. Prepare teaching materials for physics learning which is filled with energy literacy

6. Prepare LKS for physics learning which is loaded with energy literacy

- $73 \%$ respondents have not compiled teaching materials that are literated with energy

- $81 \%$ has not yet compiled LKS which is charged with energy literacy

7. Choosing a medium for physics learning that is charged with energy literacy

8. Developing media for physics learning that has energy literacy

9. Develop test instruments for indicators of achievement of competencies related to energy literacy

10. Develop non-test instruments for indicators of achievement of competencies related to energy

- $48 \%$ has not selected a medium that has energy literacy literacy

73\% have not developed energy-laden media

- $68 \%$ respondents have not yet set up test instruments related to energy literacy

- $73 \%$ have not yet developed non-test instruments related to energy literacy

Table 4. Form of training desired by respondents.

\begin{tabular}{lc}
\hline \multicolumn{1}{c}{ Statement } & Teacher's response in percent \\
\hline Carried out on weekdays (Mon-Fri) & 47 \\
Does not interfere with teaching duties (Only held on MGMP day) & 83 \\
Can use Saturday and Sunday & 54 \\
Only use "face to face" mode & 41 \\
Only using "online" mode & 24 \\
Using a combined mode (blended between face to face and online) & 86 \\
Maximum face-to-face duration of 4JP (1JP @ 45 minutes) & 69 \\
Duration face-to-face per day 4JP to 10JP (1JP @ 45 minutes) & 52 \\
The training methods vary (lectures, demonstrations, practices, & 98 \\
discussions, and independent assignments) & \\
To strengthen understanding, there needs to be an independent & 84 \\
assignment & \\
\hline
\end{tabular}


Table 5. Subject of training required.

\begin{tabular}{llc}
\hline \multicolumn{1}{c}{ Subject of Training } & Teacher's response in percent \\
\hline a. & Theory of Energy Literacy & 95 \\
b. Identify physical content related to energy literacy and for & 95 \\
& example & 92 \\
c. Identify potential local environments and examples & 95 \\
d. Identify KD-KD related energy literacy and for example & 93 \\
e. Development of indicators of achievement of competencies & \\
$\quad$ related to energy literacy and for example & 96 \\
f. Development of integrated physics RPP content of energy & \\
literacy and for example & 95 \\
g. Development of physics LKS integrated energy literacy & \\
content and for example & 93 \\
h. Development of integrated physics media energy literacy & content and examples & 95 \\
i. Development of an integrated physics learning test & \\
instrument of energy literacy content and examples & 94 \\
j. The development of non physically integrated learning & physics test content of energy literacy content and examples & \\
\hline
\end{tabular}

The subject of this training is the materials they have not learned in the preservice program when they are studying at LPTK. Besides that the material chosen respondents is material that has not been studied in the inservice program either training program by the ministry of education or by other institutions.

\section{CONCLUSION}

Physical learning has an opportunity to contribute to the development of student energy literacy. Teachers are expected to play an optimal role, so that knowledge, attitude, and behavior can be an example for students in developing energy literacy. In addition, the competence of teachers in implementing physics learning that integrates energy literacy needs to be improved through various programs. Professional communities such as the MGMP are an appropriate forum for improving the professionalism of teachers. Training programs should be synchronized with the MGMP program so as not to undermine the teacher's primary obligation as an educator in the school. The training modes that the teacher is interested in are blended training that incorporates face-to-face mode on MGMP day and the next online mode on weekdays.

\section{REFERENCES}

BPPT. (2016). Pengembangan Energi untuk Mendukung Industri Hijau. Jakarta: Pusat
Teknologi Sumber Daya Energi dan Industri Kimia.

DOE. (2017). Energy Literacy: Essential Principles and Fundamental Concepts forEnergy Education. Washington DC: US Departemen of Energy.

D. Hendrickson, K. Corrigan, A. Keefe, D. Shaw, S. Jacob, L. Skelton, J. Schon, K.B. Eitel, R.J. Hougham. (2015). Global Sustainability: An Authentic Context for Energy Education. Journal of Sustainability Education, 8.

G.Celtin, \& S.H. Nisanci. (2010). Enhancing students'environmental awareness. Procedia Social and Behavioral Sciences, 2, pp. 18301834.

J. DeWaters, \& S. Powers. (2011). Energy literacy of secondary students in New York State (USA): A measure of knowledge, affect, and behavior. Energy Policy, 39(3), pp. 16991710.

K.-L. Chen, S.-H. Huang, S.-Y. Liu. (2013). Devising a framework for energy education in Taiwan using the analytic hierarchy process. Energy Policy, 55, pp. 396-403.

K.-L. Chen, S.-Y. Liu, P.-H. Chen. (2015). Assessing Multidimensional Energy Literacy of Secondary Students Using Contextualize Assessment", International Journal of 
Soni Sukendar \& Agus Setiawan / JSER 2018, 2(1), 30

Environmental \& Science Education, 10(2), pp. 201-218.

K.-L.Chen, S.-H. Huang, S.-Y. Liu, P.-H., Chen. (2014). Energy Literacy of Secondary Students in Taiwan: A Computer-based Assessmen,. SDIWC, pp. 87-96.

McCaffrey, M. S. (2015). The Energy Climate Literacy Imperative: Why Energy Education Must Close the Loop on Changing Climate. Journal of Sustainability Education, 8.

M.A. Samsudin, A.H. Harun, N. Nordin, N.H. Haniza, C.A. Talib. (2014). The Effect of Online Project-Based Learning on Students' Attitudes towards Renewable Energy", Malaysian Journal of Distance Education, 16(2), pp. 39-57.

M. Yusup. (2017). Analisis Kurikulum Fisika SMA dalam Perspektif Literasi Energi”, Jurnal Inovasi dan Pembelajaran Fisika, 4 (1), pp. 48-53.

O. Bamisile, S. Abbasoglu, M. Dagbasi, M. Garba. (2016). Evaluation of Energy Literacy among
Nigerian Senior Secondary Students", Research \& Reviews: Journal of Educational Studies, 3(1), pp. 11-18.

Sukardiyono \& Dadan Rosana. (2017). Implementation of integrated science instruction assessment as an alternative to measure science process skills and social attitudes. Journal of Science Education Research Vol 1, No 1.

W. Singhirunnusorn, P. Luesopa, J.Pansee, N. Sahachaisaeree. (2014). Students' Behavior towards Energy Conservation and Modes of Transportation: A Case Study in Mahasarakham University. Procedia - Social and Behavioral Sciences, 35, pp. 764-771.

Y. Akitsu, K.N. Ishihara, H. Okumura, E. Yamasue. (2017). Investigating energy literacy and its structural model for lower secondary students in Japan. International Journal of Environmental \& Science Education, 12(5), pp. 1067-1095. 